\title{
Type 2 Diabetes Mellitus remission eighteen months after Roux-en-Y gastric bypass.
}

\section{Remissão do Diabetes Mellitus Tipo 2 dezoito meses após gastroplastia com derivação em Y-de-Roux.}

Marcelo Gomes Girundi, TCBC-MG'1.

\begin{abstract}
A B S T R A C T
Objective: to evaluate the effectiveness of Roux-en-Y gastric bypass in improving the glycemic profile of obese patients with type 2 Diabetes Mellitus (DM2) after 18 months of follow-up. Methods: four hundred sixty-eight pacients with DM2 and BMI $\geq 35$ were submitted to Roux-en-Y gastric bypass, from 1998 to 2010. All patients were submitted to glycemic control analysis in the 3rd, 6th, 9th, 12th and 18th postoperative months. We considered: type 2 diabetic patients, the ones with fasting glucose $\geq 126 \mathrm{mg} / \mathrm{dl}$ and $\mathrm{HbA} 1 \mathrm{C} \geq 6.5$ in two dosages; high risk patients for diabetes, those who presented fasting glucose $\geq 100$ to $125 \mathrm{mg} / \mathrm{dl}$ and $\mathrm{HbA} 1 \mathrm{C}$ between $5.7 \%-6.4 \%$; and normal patients, those presenting glucose $<100 \mathrm{mg} / \mathrm{dl}$ and $\mathrm{HbA} 1 \mathrm{C}<5.7 \%$. Such diagnostic criteria were based on the official position of Sociedade Brasileira de Diabetes, published in July, 2011. Results: The remission of DM2 was seen in 410 (87.6\%) out of 468 patients 18 months after the surgery, that being a meaningful difference, with $p<0.001$. Fourty-eight (10.3\%) patients sustained criteria for the disease and ten (2.1\%) continued at high risk for DM2. Conclusions: Roux-en-Y gastric bypass was effective in the promotion and maintaince of long-term glycemic control. There are evidences showing that the remission of DM2 is not only related to weight loss and that other enteroinsular axis mechanisms must be involved.
\end{abstract}

Keywords: Bariatric Surgery. Diabetes Mellitus, Type 2. Gastric Bypass. Obesity. Gastroplasty.

\section{INTRODUCTION}

$\mathrm{O}$ besity is a serious problem of public health worldwide, affecting developed and developing countries. People with a BM $>30 \mathrm{~kg} / \mathrm{m}^{2}$ represent $7 \%$ of the global population'. According to a survey organized by the Sociedade Brasileira de Cirurgia Bariátrica e Metabólica, $51 \%$ of Brazilians are overweight ${ }^{2}$. Obesity is an independent risk factor for the development of various associated diseases such as type-2 diabetes mellitus (DM2), hypertension (HT), dyslipidemia, metabolic syndrome (MS), hepatic steatosis, gastroesophageal reflux disease, cholelithiasis, among others ${ }^{2}$.

Diabetes mellitus is the most common metabolic disease in Western countries, with an estimated 300 million people affected in 2025 , of which $90 \%$ will be carriers of DM2. There is also a strong association between obesity and type- 2 diabetes, and $80 \%$ of patients with type-2 diabetes have some degree of obesity ${ }^{3}$. Diabetes is a major cause of mortality and early disability. An increasing body of evidence suggests that most of the complications of diabetes can be prevented or delayed by prospective treatment of hyperglycemia. The timing and quality of therapy, consequences of early diagnosis and immediate continued control of hyperglycemia, are crucial to improving outcomes ${ }^{4}$.

Surgical treatment of obesity has been documented as the most effective for obesity of large proportions, both in loss of excess weight and in its long-term maintenance, as well as to the improvement of comorbidities, among these DM2. Previous studies demonstrate the clinical resolution of DM2 in $48 \%$ of patients undergoing adjustable gastric banding, 84\% after vertical Roux-en-Y gastroplasty and 98\% after biliopancreatic diversion ${ }^{5}$. The remission of DM2 after adjustable gastric banding is proportional to the weight loss; however, the remission of DM2 after mixed and predominantly disabsorptive procedures occurs more effectively and more quickly, even before weight loss, suggesting a participation of the small intestine in the

1 - Serviço de Cirurgia Geral do Complexo São Francisco, Belo horizonte, MG, Brasil. 
metabolic benefits, a fact also demonstrated in pioneering works from Rubino et al. ${ }^{6}$.

The aim of this study is to evaluate the effectiveness of Roux-en-Y gastric bypass (RYGB) in improving glycemic control in obese patients with $\mathrm{BMI} \geq 35$ who meet the criteria for DM2.

\section{METHODS}

We obtained the study sample by convenience, patients being selected prospectively and consecutively, constituting a observational, descriptive and longitudinal study. The selection of patients was based on the recommendations of the Sociedade Brasileira de Cirurgia Bariátrica e Metabólica. An interdisciplinary team clinically evaluated the patients. The protocol was approved by the Ethics in Research Committee (chsf-005/98) and all patients signed an informed consent before entering the study.

RYGB was performed in 5211 patients with $\mathrm{BMI} \geq 35$ in the presence of comorbidities or $\mathrm{BMI} \geq 40$ regardless of the presence of comorbidities, either by laparotomy, comprising 4609 patients (88.4\%), or by laparoscopy, 602 patients (11.6\%), by the same surgical team at São Francisco, Mater Dei and Lifecenter Hospitals between May 1998 and December 2010.

Of these 5211 cases, 492 patients were considered as having type- 2 diabetes mellitus, ie patients with fasting glucose $\geq 126 \mathrm{mg} / \mathrm{dL}$ and $\mathrm{HbA} 1 \mathrm{C} \geq 6,5 \%$ in two different dosages.

Clinical follow-up was performed in 468 patients during the 18-month period, through quarterly outpatient visits in the first year and twice in the second year. The fasting glucose and $\mathrm{HbA} 1 \mathrm{C}$ were measured in the third, sixth, ninth, 12th and 18th months postoperatively. The evaluation was made by the same multidisciplinary team. According to the analysis of glycemic control in the postoperative period, the patients were divided into three groups and repositioned over the 18 months of follow-up: Group A- Patients with disease remission: fasting blood glucose $<100 \mathrm{mg} / \mathrm{dL}$ and $\mathrm{HbA} 1 \mathrm{C}<5.7 \%$; Group B- Patients with increased risk for diabetes: fasting glucose between 100 and $125 \mathrm{mg} / \mathrm{dL}$ and $\mathrm{HbA} 1 \mathrm{c}$ between 5.7\% and 6.4\%; Group C- patients with DM2 un- changed: fasting glucose $\geq 126 \mathrm{mg} / \mathrm{dL}$ and $\mathrm{HbA} 1 \mathrm{c} \geq 6,5 \%$. These diagnostic criteria are in line with the position of the Sociedade Brasileira de Diabetes?

The gastric pouch was performed with the use of linear cutting staplers and endoscopic staplers molded by a Fouchet catheter, leaving a capacity of approximately $30 \mathrm{ml}$, with or without silicone ring. The gastrojejunal anastomosis was performed with mechanical and manual sutures with a diameter between 1.5 and $2.0 \mathrm{~cm}$; the biliopancreatic loop had $100 \mathrm{~cm}$ and food loop, $150 \mathrm{~cm}$.

In order to verify whether there was a statistically significant and consecutive improvement in blood sugar levels over time, we used the McNamer test (Agresti, 2002). To evaluate the percentage of improvement between genders at each follow-up time, we used the chi-square test (Agresti, 2007). We set up a marginal regression (Liang and Zeger, 1986) for binary data to enable multiple inferences of patient improvement, without sample stratification, gaining statistical power. The Marginal model has been preferred as an extension of the Generalized Linear Models for longitudinal data (Fitzmaurice, 2011) due to its ease of interpretation and lack of distributional assumptions. The marginal regression was adjusted considering an unstructured working matrix. The software used in the analysis was the " $R$ " version 2.15.0.

\section{RESULTS}

Of the 492 selected patients, 24 were lost to follow-up; one of them died in the early postoperative period due to pulmonary thromboembolism. Of the 468 remaining patients, there was a remission of type-2 diabetes after 18 months of surgery in 410 (87.6\%), placed in Group A, this difference being significant, with $p<0.001$. Ten patients $(2.1 \%)$ remained with increased risk for DM2, placed in Group B. Disease criteria remained in 48 patients (10.3\%), allocated in group C.

When analyzing the evolution of the results in Table 1, we observed the progression of DM2 remission every quarter. Only in the period from 12 to 18 months, the remission of the disease was not significant by the McNamer test $(p=0.134)$, with no evidence of improvement in the latter semester (Figure 1). 
Table 1. Contingency for the distribution of the times between groups after surgery.

\begin{tabular}{ccccccccc}
\hline \multirow{2}{*}{ Times after surgery (months) } & \multicolumn{7}{c}{ Groups } \\
\cline { 2 - 9 } & \multicolumn{2}{c}{ C } & \multicolumn{1}{c}{ B } & \multicolumn{1}{c}{ A } & \multicolumn{2}{c}{ Total } \\
\hline 3 & 259 & $55.3 \%$ & 17 & $3.6 \%$ & 192 & $41.0 \%$ & 468 & $100 \%$ \\
6 & 210 & $44.9 \%$ & 13 & $2.8 \%$ & 245 & $52.4 \%$ & 468 & $100 \%$ \\
9 & 75 & $16.0 \%$ & 3 & $0.6 \%$ & 390 & $83.3 \%$ & 468 & $100 \%$ \\
12 & 60 & $12.8 \%$ & 2 & $0.4 \%$ & 406 & $86.8 \%$ & 468 & $100 \%$ \\
18 & 48 & $10.3 \%$ & 10 & $2.1 \%$ & 410 & $87.6 \%$ & 468 & $100 \%$ \\
\hline
\end{tabular}

In the evaluated series, there were $330(70.5 \%)$ female patients and $138(29.5 \%)$ male ones. The mean age was $40.7 \pm 10.6$ years (range 18-69).

The analysis of groups distribution over time was stratified by gender (Figure 2).

Through regression analysis, we can infer that there is no significant difference in remission between genders over time ( $p=0.092)$. There was a significant difference between the periods for remission $(p<0.001)$, and the chance of DM2 remission at six months was 1.58 times (1.41-1.78) the chance in the third month; between the ninth and the sixth months, 4.58 times (3.66-5.74); and between the 12th and the ninth month, 1.31 (1.15-1.49). There was also a significant difference between the 18th and 12th month $(p=0.044)$, and the chance of finding a patient with remission of DM2 in the 18th month was 1.09 (1.00-1.16) times the chance in the 12th month.

\section{DISCUSSION}

The main mechanisms for the remission of DM2 after RYGB are restricted caloric intake, reduction of ghrelin, which stimulates the reduction of appetite,

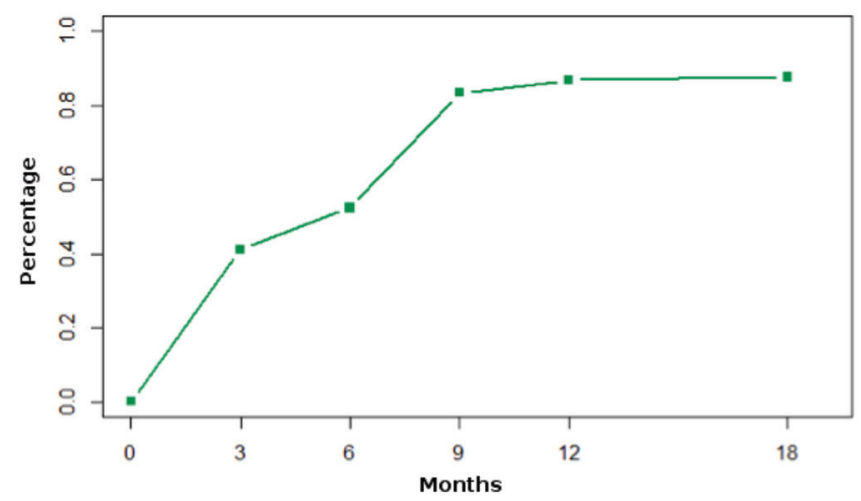

Figure 1. Percentage of patients with DM2 remission over time. intestinal malabsorption, weight loss, with reduction of visceral fat, reducing insulin resistance, increased metabolic rate, and especially modulation of gastrointestinal hormones, the incretins ${ }^{8-15}$.

The incretins are intestinal peptides that stimulate insulin secretion after food ingestion. The two major gastrointestinal hormones identified as incretins are GIP (gastric inhibitory peptide) and GLP-1 (glucagon-like peptide-1). GIP is secreted by K-cells mainly located in the duodenum and proximal jejunum, while GLP-1 is secreted by the L-cells found primarily in the ileum. The incretins are rapidly secreted during a meal, circulate in the blood and have a relatively short half life (3-7 minutes), since they are rapidly inactivated by DPP-IV (dipeptidyl peptidase-IV). Certainly the participation of other hormones such as ghrelin, PYY (peptide YY), leptin and others, plays an important role in glucose homeostasis ${ }^{15}$. The results of this study corroborate previous ones $8,15,16$ in that they associate RYGB with such hormone modulation, so as to provide an increase in insulin sensitivity and improved beta-cell function, with recovery of insulin secretion in response to the incretin stimulation ${ }^{16}$.

We obtained $87.6 \%$ of remission of type- 2 diabetes and many of these results were observed in the early
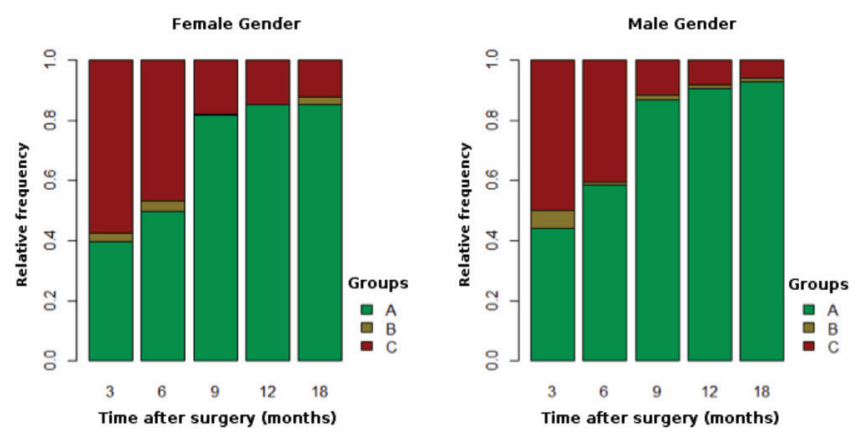

Figure 2. Distribution of groups between times after surgery, stratified by gender. 
postoperative period, before significant weight loss, which corroborates the hypothesis mentioned above. On the other hand, patients that had not complete remission had a slower evolution as for results improvement. Patients with longer time of disease progression, associated with chronic use of insulin before surgery, may show greater functional impairment of beta cell capacity. Because of this, we suggest the dosage of C-peptide in subsequent studies.

The effects of surgery on diabetes control are overwhelming, but the validity of available data is questionable. Methodological flaws are dute to lack of adequate control groups and to the short duration of the evaluation period. Bariatric surgery may have adverse effects for life, such as nutritional deficiencies and osteoporosis, which can appear and worsen after years of follow-up ${ }^{17}$. In addition, diabetes is a chronic disease, and expressions such as healing, remission and improved disease should be used with prudence.

Multidisciplinary teams are essential in assisting surgery. Undoubtedly, clinical, endocrinological, nutritional, physiotherapeutical and psychological control, as well as regular, oriented physical activity can improve surgical outcome.

\section{R E S U M O}

Objetivo: avaliar a eficácia da gastroplastia com derivação em Y-de-Roux, em pacientes obesos e portadores de Diabetes Mellitus tipo 2 (DM2), na melhoria do perfil glicêmico após 18 meses de seguimento. Métodos: foram submetidos à derivação gástrica em Y-de-Roux 468 pacientes com IMC $\geq 35$ e portadores de DM2, no período de 1998 a 2010. Todos os pacientes tiveram a análise do controle glicêmico realizadas no terceiro, sexto, nono, 12ํㅡ e 18 o meses de pós-operatório. Os critérios diagnósticos de diabetes foram baseados no Posicionamento Oficial da Sociedade Brasileira de Diabetes, publicado em julho de 2011. Resultados: observou-se a remissão do DM2 em 410 pacientes $(87,6 \%)$ após 18 meses da cirurgia, sendo essa diferença significativa com p-valor $<0,001$. A doença se manteve inalterada em 48 pacientes (10,3\%), e dez pacientes (2,1\%) permaneceram com o risco aumentado para DM2. Conclusão: a gastroplastia com derivação em Y-de-Roux foi efetiva na promoção e manutenção do controle glicêmico em longo prazo.

Descritores: Cirurgia Bariátrica. Diabetes Mellitus Tipo 2. Derivação Gástrica. Obesidade. Gastroplastia.

\section{REFERENCES}

1. Seidell JC. The epidemiology of obesity. In: Bjöntorp $P$, editor. Internacional textbook of obesity. New York: John Wiley and Sons; 2001. p.23-9.

2. Must A, Spadano J, Coakley EH, Field $A E$, Colditz G, Dietz WH. The disease burden associated with overweight and obesity. JAMA. 1999;282(16):1523-9.

3. Geloneze B, Geloneze SR, Fiori C, Stabe C, Tambascia
$M A$, Chaim EA, et al. Surgery for nonobese type 2 diabetic patients: an interventional study with duodenaljejunal exclusion. Obes Surg. 2009;19(8):1077-83.

4. Inzucchi SE, Sherwin RS. Diabetes mellitus. In: Goldman L, Ausiell D, editores. Cecil Medicina. Rio de Janeiro: Elsevier; 2009. p.1988-2013.

5. Buchwald $H$, Avidor $Y$, Braunwald $E$, Jensen MD, Pories W, Fahrbach K, et al. Bariatric surgery: a systematic review and meta-analysis. JAMA; 2004;292(14):1724-37. 
6. Rubino F, Forgione A, Cummings DE, Vix M, Gnuli D, Mingrone $G$, et al. The mechanism of diabetes control after gastrointestinal bypass surgery reveals a role of proximal intestine in the pathofisiology of type 2 diabetes. Ann Surg. 2006;244(5):741-9.

7. Sociedade Brasileira de Diabetes (SBD). Algoritmo para o tratamento do diabetes tipo 2 - atualização 2011. Posicionamento oficial SBD número-2011. Disponível em: http://www.nutritotal.com.br/diretrizes/files/230-PosicionamentoSBD2011.pdf

8. Buchwald H, Williams SE. Bariatric surgery worldwide 2003. Obes Surg. 2004;14(9):1157-64.

9. Carvalho PS, Moreira CLCB, Barelli MC, Oliveira FH, Guzzo MF, Miguel GPS, et al. Cirurgia bariátrica cura síndrome metabólica? Arq Bras Endocrinol Metab. 2007;51(1):79-85.

10. Frühbeck G, Diez Caballero A, Gil MJ. Fundus functionality and ghrelin concentrations after bariatric surgery. N Engl J Med. 2004;350(3):308-9.

11. Nijhuis J, van Dielen FM, Buurman WA, Greve JW. Ghrelin, leptin and insulin levels after restrictive surgery: a 2-year follow-up study. Obes Surg. 2004;14(6):783-7.

12. Geloneze B, Tambascia MA, Pilla VF, Geloneze SR, Repetto EM, Pareja JC. Ghrelin: a gut-brain hormone: effect of gastric bypass surgery. Obes Surg. 2003;13(1):17-22.

13. Vidal J, Ibarzabal A, Romero F, Delgado S, Momblán D, Flores $L$, et al. Type 2 diabetes mellitus and the metabolic syndrome following sleeve gastrecmomy in severely obese subjects. Obes Surg. 2008;18(9):1077-82.
14. Miguel GPS, Azevedo JLMC, Carvalho PS, Fukuda T, Novaes MA, Kumaira SB, et al. Baroendocrine Mason operation. Abstract. Obes Surg. 2006;16:1020-1.

15. Bose $M$, Oliván $B$, Teixeira J, Pi-Sunyer FX, Laferrère $B$. Do incretins play a role in the remission of type 2 diabetes after gastric bypass surgery: what are the evidence? Obes Surg. 2009;19(2):217-29.

16. Geloneze B, Pareja JC. Cirurgia bariátrica cura síndrome metabólica? Arq Bras Endocrinol Metab. 2006;50(2):400-7.

17. Koch TR, Finelli FC. Postoperative metabolic and nutritional complications of bariatric surgery. Gastroenterol Clin North Am. 2010;39(1):109-24.

18. Pories WJ, MacDonald KG Jr, Flickinger EG, Dohm $\mathrm{GL}$, Sinha MK, Barakat HA, et al. Is type II diabetes mellitus (NIDDM) a surgical disease? Ann Surg. 1992;215(6):633-42; discussion 643.

19. Cohen R, Torres MC, Schiavon CA. Cirurgia metabólica: mudanças na anatomia gastrintestinal e a remissão do diabetes mellitus tipo 2. $A B C D$, arq bras cir dig. 2010;23(1):40-5.

Recebido em: 11/12/2015

Aceito para publicação em: 31/03/2016

Conflito de interesse: nenhum.

Fonte de financiamento: nenhuma.

\section{Endereço para correspondência:}

Marcelo Gomes Girundi

E-mail: marcelogirundi@gmail.com 